University of Nebraska - Lincoln

DigitalCommons@University of Nebraska - Lincoln

Biological Systems Engineering: Papers and

Publications

Biological Systems Engineering

4-2007

\title{
Potential of Agricultural Residues and Hay for Bioethanol Production
}

\author{
Ye Chen \\ North Carolina State University at Raleigh \\ Ratna R. Sharma-Shivappa \\ North Carolina State University \\ Deepak R. Keshwani \\ University of Nebraska-Lincoln, dkeshwani2@unl.edu \\ Chengci Chen \\ Central Agricultural Research Center, Montana State University
}

Follow this and additional works at: https://digitalcommons.unl.edu/biosysengfacpub

Part of the Biological Engineering Commons

Chen, Ye; Sharma-Shivappa, Ratna R.; Keshwani, Deepak R.; and Chen, Chengci , "Potential of Agricultural Residues and Hay for Bioethanol Production" (2007). Biological Systems Engineering: Papers and Publications. 79.

https://digitalcommons.unl.edu/biosysengfacpub/79

This Article is brought to you for free and open access by the Biological Systems Engineering at DigitalCommons@University of Nebraska - Lincoln. It has been accepted for inclusion in Biological Systems Engineering: Papers and Publications by an authorized administrator of DigitalCommons@University of Nebraska Lincoln. 
Published in Applied Biochemistry and Biotechnology Part A: Enzyme Engineering and Biotechnology 142 (2007), pp. 276-290; doi: 10.1007/s12010-007-0026-3 Copyright (C) 2007 Humana Press Inc. (Springer

Verlag). Used by permission. http://www.springerlink.com/content/a2542710357w3u12

\title{
Potential of Agricultural Residues and Hay for Bioethanol Production
}

\author{
Ye Chen, ${ }^{1}$ Ratna R. Sharma-Shivappa, ${ }^{1}$ \\ Deepak Keshwani, ${ }^{1}$ and Chengci Chen ${ }^{2}$ \\ ${ }^{1}$ Department of Biological and Agricultural Engineering, \\ North Carolina State University, Campus Box 7625, Raleigh, NC 27695-7625, USA \\ ${ }^{2}$ Central Agricultural Research Center, Montana State University, Moccasin, MT, USA \\ Corresponding author - R. R. Sharma-Shivappa, email ratna_sharma@ncsu.edu
}

\begin{abstract}
Production of bioethanol from agricultural residues and hays (wheat, barley, and triticale straws, and barley, triticale, pearl millet, and sweet sorghum hays) through a series of chemical pretreatment, enzymatic hydrolysis, and fermentation processes was investigated in this study. Composition analysis suggested that the agricultural straws and hays studied contained approximately $28.62-38.58 \%$ glucan, $11.19-20.78 \%$ xylan, and $22.01-$ $27.57 \%$ lignin, making them good candidates for bioethanol production. Chemical pretreatment with sulfuric acid or sodium hydroxide at concentrations of $0.5,1.0$, and $2.0 \%$ indicated that concentration and treatment agent play a significant role during pretreatment. After $2.0 \%$ sulfuric acid pretreatment at $121^{\circ} \mathrm{C} / 15$ psi for $60 \mathrm{~min}, 78.10-81.27 \%$ of the xylan in untreated feedstocks was solubilized, while $75.09-84.52 \%$ of the lignin was reduced after $2.0 \%$ sodium hydroxide pretreatment under similar conditions. Enzymatic hydrolysis of chemically pretreated $\left(2.0 \% \mathrm{NaOH}\right.$ or $\left.\mathrm{H}_{2} \mathrm{SO}_{4}\right)$ solids with Celluclast $1.5 \mathrm{~L}-$ Novozym 188 (cellobiase) enzyme combination resulted in equal or higher glucan and xylan conversion than with Spezyme ${ }^{\circledR}$ CP- xylanase combination. The glucan and xylan conversions during hydrolysis with Celluclast $1.5 \mathrm{~L}$-cellobiase at $40 \mathrm{FPU} / \mathrm{g}$ glucan were 78.09 to $100.36 \%$ and 74.03 to $84.89 \%$, respectively. Increasing the enzyme loading from 40 to $60 \mathrm{FPU} / \mathrm{g}$ glucan did not significantly increase sugar yield. The ethanol yield after fermentation of the hydrolyzate from different feedstocks with Saccharomyces cerevisiae ranged from 0.27 to $0.34 \mathrm{~g} / \mathrm{g}$ glucose or $52.00-65.82 \%$ of the theoretical maximum ethanol yield.
\end{abstract}

Keywords: chemical pretreatment, enzymatic hydrolysis, feedstocks, fermentation, glucan, lignin, xylan 


\section{Introduction}

The United States consumes approximately $25 \%$ of the world's oil and natural gas supply [1] and imports $60 \%$ of this quantity [2]. National security concerns and a realization that fossil fuels are limited have stimulated the need for investigating technologies to convert lignocellulosic biomass to ethanol for fuel [3]. Biomass such as agricultural and aquatic crops and residues, herbaceous and woody energy crops, and forestry residues offer a tremendous opportunity to use domestic and sustainable resources to meet the nation's fuel needs [4]. However, currently, only $6 \%$ of the total energy consumption in the US comes from plant and plant-derived materials. Biofuels, such as ethanol from biomass and biodiesel from vegetable oil, clean our air, support rural economies, and improve energy independence and balance of trade, thus, holding promise for the future.

Corn is currently the most important feedstock for the ethanol industry in the United States. However, the ten major corn-producing states are mainly located in the Midwest. Given the low density of biomass, expenses associated with transportation of biomass to ethanol facilities outside the corn production area are high. Therefore, it is essential to diversify and explore alternative feedstocks including cereal grains and their agricultural residues, especially for areas where corn is not widely grown. This can help lower transportation expenses and reduce dependence on corn, which is also an important food source.

In 2004, small grain production in the United States was 6.08 million tons of barley, 0.34 million tons of pearl millet, 11.53 million tons of sorghum, and 58.75 million tons of wheat [5]. Hundreds of million tons of residue was left behind as a by-product of these crops upon harvest. These agricultural residues are generally allowed to decompose in the fields or are burned. Combustion of agricultural residue contributes significantly to air pollution and global warming. In addition, farmers and ranchers in the US also produce more than 150 million tons of hay and silage annually for livestock feed [6]. Using winter annual triticale and sweet sorghum and pearl millet for double-cropping (two harvests per year), biomass production can be further increased as much as $60 \%$ in the Northern Great Plains [7]. These annual and/or perennial grasses and cereal forage crops may serve dual purposes as livestock feed and lignocellulosic feedstock for ethanol production.

Composition analysis suggests that agricultural residues, which are primarily composed of stalks, leaves, and straws contain approximately 10-20\% lignin, $40-50 \%$ glucan, and 15-35 xylan, making them good candidates for bioethanol production through proper pretreatment, hydrolysis, and fermentation [8]. However, depending on the origin of the biomass, pretreatment methods applied, and yeast culture used, the ethanol yield can vary greatly from 31 to $84 \%$ of the theoretical maximum value for wheat straw [9-12] and 58 to $88 \%$ for corn stover [15-18]. It is, therefore, necessary to develop conversion methods for various feedstocks based on optimum pretreatment, hydrolysis, and fermentation conditions.

Hence, the objectives of this study were to: (1) determine the chemical compositions of wheat, barley, and triticale straws (residue after grain harvesting) and triticale, barley, sweet sorghum, and pearl millet hays (harvested when crops are green), (2) investigate suitable acid or alkali pretreatment conditions for different feedstocks, (3) compare efficiency of different enzymes and their concentrations during hydrolysis, (4) determine ethanol yield using selected yeast fermentations. 


\section{Materials and Methods}

\section{Feedstocks}

Feedstock samples used for this study were obtained from a cropping system study that compared biomass production potentials of an irrigated single cropping to a double cropping system on a producer's land in central Montana. The single cropping system was employed to plant winter triticale for grain and straw, and had one harvest per year, while the double cropping system was employed to plant winter triticale for forage. Sweet sorghum and pearl millet were planted for hay immediately after harvesting triticale forage in late June. Wheat, barley, and triticale straw and barley and triticale hay samples were collected from the nearby fields at the Central Agricultural Research Center of Montana State University. The fields were under typical dryland single cropping production practices.

The feedstocks (barley hay, barley straw, pearl millet hay, sweet sorghum hay, triticale hay, triticale straw, and wheat straw) were chopped and further ground to pass a 1-mm sieve in a Thomas Wiley Laboratory Mill (model no. 4). The samples were stored in sealed plastic bags at room temperature until use for pretreatment.

\section{Enzymes}

Cellulase (Celluclast 1.5 L) produced by Trichoderma reesei and cellobiase (Novozyme 188) produced by Aspergillus niger were purchased from Sigma-Aldrich Chemical Co (St. Louis, MO). Spezyme ${ }^{\circledR}$ CP cellulase and Multifect ${ }^{\circledR}$ xylanase of T. reesei origin were obtained from Genencor International Inc. (Palo Alto, CA). All enzymes were stored at $4^{\circ} \mathrm{C}$ until use for hydrolysis of the various feedstocks. The enzymatic activities, optimum $\mathrm{pH}$, and optimum temperature are summarized in Table 1.

\section{Yeast Strain and Growth Condition}

Saccharomyces cerevisiae (ATCC 24859) obtained from the Agricultural and Biological Engineering Department at Pennsylvania State University was grown at $30 \pm 1^{\circ} \mathrm{C}$ in $100 \mathrm{ml} \mathrm{me-}$ dium containing $20 \mathrm{~g}$ glucose, $8.5 \mathrm{~g}$ yeast extract, $1.32 \mathrm{~g} \mathrm{NH}_{4} \mathrm{Cl}, 0.11 \mathrm{~g} \mathrm{MgSO}_{4^{\prime}}$ and $0.06 \mathrm{~g}$ $\mathrm{CaCl}_{2}$, per liter of deionized water. The culture was allowed to grow under aerobic conditions in a shaker incubator at $150 \mathrm{rpm}$ for $24 \mathrm{~h}$. The cells were harvested by centrifugation at $5,000 \times \mathrm{g}$ at $4^{\circ} \mathrm{C}$ for $10 \mathrm{~min}$ and washed three times with $0.1 \%$ peptone water to remove excess media and resuspended in $30 \mathrm{ml}$ peptone before use. One milliliter liquid sample was taken to measure the dry matter (\%) of the inoculum. The dry matter (\%) content was then used to determine the volume of the yeast used to inoculate the hydrolyzate.

Table 1. Characteristics of enzymes.

\begin{tabular}{|c|c|c|c|c|c|c|}
\hline Enzyme & $\begin{array}{l}\text { Enzymatic } \\
\text { activity }\end{array}$ & $\begin{array}{l}\text { Optimal } \\
\mathrm{pH}\end{array}$ & $\begin{array}{l}\text { Optimal } \\
\text { temp. }\left({ }^{\circ} \mathrm{C}\right)\end{array}$ & $\begin{array}{l}\beta \text {-Glucosidase } \\
\text { activity }\end{array}$ & $\begin{array}{l}\text { Xylanase } \\
\text { activity }\end{array}$ & $\begin{array}{l}\beta \text {-Xylosidase } \\
\text { activity }\end{array}$ \\
\hline Celluclast 1.5 L & $700 \mathrm{U} / \mathrm{g}$ & $4.5-5.0$ & $55-65$ & $74^{\mathrm{c}}$ & $905^{c}$ & $15^{c}$ \\
\hline $\begin{array}{l}\text { Cellobiase } \\
\text { (Novozyme 188) }\end{array}$ & $250 \mathrm{U} / \mathrm{g}$ & $4.5-5.0$ & $55-65$ & $330^{c}$ & $605^{c}$ & $8^{c}$ \\
\hline $\begin{array}{l}\text { Spezyme CP® } \\
\text { cellulase }\end{array}$ & $82 \mathrm{GCU} / \mathrm{g}^{\mathrm{a}}$ & $4.5-5.5$ & $50-65$ & $0.35-0.46^{\mathrm{d}}$ & $\mathrm{n} / \mathrm{a}$ & $\mathrm{n} / \mathrm{a}$ \\
\hline Multifect xylanase & $8,000 \mathrm{GXU} / \mathrm{ml}^{\mathrm{b}}$ & 5.0 & $50-60$ & $\mathrm{n} / \mathrm{ae}$ & $\mathrm{n} / \mathrm{a}$ & $\mathrm{n} / \mathrm{a}$ \\
\hline
\end{tabular}

\footnotetext{
a GCU Genecor cellulase units.

${ }^{\mathrm{b}}$ GXU Genecor xylanase units.

c Saha et al. (2005) [46]; enzyme activities are in U/ml.

d Nieves et al. (1998) [39]; enzyme activities are in U/mg.

e Not available.
} 


\section{Chemical Pretreatment}

Selection of pretreatment agent was based on composition analysis of feedstocks. Sulfuric acid $\left(\mathrm{H}_{2} \mathrm{SO}_{4}\right)$ at concentrations of $0.5,1.0$, and $2.0 \%(\mathrm{w} / \mathrm{v})$ was used to pretreat $10 \mathrm{~g}$ ground barley, pearl millet, and sorghum hays at a substrate solid loading of $10 \%$ (w/v, dry weight basis). Similarly, 10 g ground barley straw, triticale hay, triticale straw, and wheat straw were pretreated with sodium hydroxide $(\mathrm{NaOH})$ at concentrations of $0.5,1.0$, and $2.0 \%(\mathrm{w} / \mathrm{v})$ and a substrate solid loading of $10 \%(\mathrm{w} / \mathrm{v}$, dry weight basis). Pretreatments were performed in triplicate in an autoclave at $121^{\circ} \mathrm{C}$ under 15 psi pressure for a residence time of $60 \mathrm{~min}$. The pretreated solids were washed with $750 \mathrm{ml}$ of hot deionized water and used for determination of total solids, acid-insoluble lignin, glucan, and xylan before storage at $4^{\circ} \mathrm{C}$ for enzymatic hydrolysis.

\section{Enzymatic Hydrolysis}

Enzymatic hydrolysis of chemically pretreated feedstocks was performed in $250 \mathrm{ml}$ Erlenmeyer flasks. Samples pretreated with $2.0 \%$ sulfuric acid or sodium hydroxide were selected for enzymatic hydrolysis at cellulase activities of 40 and $60 \mathrm{FPU} / \mathrm{g}$ glucan. Wet, pretreated samples containing $1 \mathrm{~g}$ of dry sample (as determined by moisture analysis) were mixed with $30 \mathrm{ml}$ citrate buffer $(\mathrm{pH} 4.8,50 \mathrm{mM})$ containing $40 \mu \mathrm{g} / \mathrm{ml}$ tetracycline hydrochloride (an antibiotic added to avoid microbial contamination). Sample flasks were preincubated in a shaking water bath at $55^{\circ} \mathrm{C}$ and $150 \mathrm{rpm}$ for $10 \mathrm{~min}$ before addition of the enzymes. Two sets of enzymes: Celluclast $1.5 \mathrm{~L}$ with an activity of 85.1 FPU/ $\mathrm{ml}$ enzyme solution supplemented with cellobiase (Novozyme 188) at a ratio of 1:1.75 (v/v) and Spezyme® ${ }^{\circledR}$ CP cellulase with an activity of $141.9 \mathrm{FPU} / \mathrm{ml}$ supplemented with Multifect ${ }^{\circledR}$ xylanase at a ratio of 1:1.75 (v/v), were used for hydrolysis experiments at the desired levels of cellulase activity. Excess cellobiase was added to Celluclast 1.5 L to avoid end-product inhibition due to cellobiose build-up [19]. Control samples which did not contain enzymes were also included in this study to determine the background sugar concentrations in the pretreated feedstocks. The samples were incubated in a shaking incubator at $55^{\circ} \mathrm{C}$ and $150 \mathrm{rpm}$ for $72 \mathrm{~h}$. Two milliliters hydrolyzate samples were taken at the termination of enzymatic hydrolysis, immediately chilled on ice, and centrifuged at 5,000×g for $10 \mathrm{~min}$. The supernatant was analyzed for fermentable sugar content.

\section{Fermentation}

Hydrolyzates from enzymatic hydrolysis treatments with Celluclast 1.5 L- cellobiase at $40 \mathrm{FPU} / \mathrm{g}$ glucan were centrifuged at 5,000 $\times \mathrm{g}$ for $10 \mathrm{~min}$. Twenty milliliters of supernatant was transferred to $100 \mathrm{ml}$ serum bottles for fermentation. The hydrolyzate was then adjusted to $\mathrm{pH} 7$ by adding $2 \mathrm{~N} \mathrm{NaOH}$ and inoculated with $S$. cerevisiae at a cell concentration of $10 \mathrm{~g}$ dry matter/1 [20]. All samples were then incubated at $30 \pm 1^{\circ} \mathrm{C}$ for $72 \mathrm{~h}$. Liquid samples were analyzed for ethanol content after fermentation.

\section{Analysis Methods}

The total solids, ash, and acid-soluble and acid-insoluble lignin contents of the untreated feedstocks and the solid fractions remaining after pretreatment were determined by Laboratory Analytical Procedures [21-23]. Holocellulose (combination of hemicellulose and cellulose) was determined for untreated feedstocks by the gravimetric methods developed by Han and Rowell [24].

The carbohydrate content of the untreated and pretreated feedstocks and hydrolyzates from enzymatic hydrolysis was determined by measuring the monomeric sugars 
(arabinose, galactose, glucose, and xylose). All samples were neutralized with $\mathrm{Ba}(\mathrm{OH})_{2^{\prime}}$ centrifuged at 5,000×g for $10 \mathrm{~min}$, and filtered through $0.22-\mu \mathrm{m}$ Milipore filters before analysis. The structural carbohydrates laboratory analytical procedure from NREL was modified for use with a Dionex-300 high performance liquid chromatography (HPLC) system [23]. The HPLC system was equipped with a CarboPac ${ }^{\mathrm{TM}}$ PA10 $(4 \times 250 \mathrm{~mm})$ anion exchange column, a guard column $(4 \times 50 \mathrm{~mm})$, an automated sampler, a gradient pump, and a pulsed amphometric detector (PAD) with a gold working electrode (Dionex Corp., Sunnyvale, CA). The mobile phase used was $10 \mathrm{mM} \mathrm{NaOH}$ at a flow rate of $1 \mathrm{ml} / \mathrm{min}$. Monomeric sugars at concentrations of $0,10,30$, and $50 \mathrm{mg} / 1$ were used as standards.

Ethanol content in the fermentation broth was analyzed by an assay procedure [25]. All samples were centrifuged at 5,000×g for $10 \mathrm{~min}$ before analysis. The ethanol yield was calculated as a percentage of theoretical maximum ethanol yield $\left(Y_{\max }\right)$ as per Equation (1) [15].

$$
Y_{\max }(\%)=E \div(G \times 0.511) \times 100
$$

where $E$ and $G$ represent ethanol (g) produced during fermentation and glucose $(\mathrm{g})$ in the hydrolyzates, respectively. The constant 0.511 is the theoretical yield of ethanol produced from glucose.

\section{Data Analysis}

All treatments in this study were conducted in triplicate. Significant and nonsignificant differences between treatments were evaluated by performing Tukey simultaneous tests under PROC MEANS at a 95\% confidence level. All statistical tests were performed by SAS 8.0 software (SAS Institute Inc., Cary, NC).

\section{Results and Discussions}

\section{Characterization of Feedstocks}

The lignocellulosic feedstocks were characterized for their main constituents (Table 2). Holocellulose fraction, which represents carbohydrates in biomass varied from $40.58-$ $58.46 \%$. Glucan, which is derived from plant cell wall and xylan, which is the major hemicellulose constituent, represented the major carbohydrate components in the feedstocks. Arabinan (less than 3\%) and galactan (less than $0.5 \%$ ) accounted for only a small portion of the feedstocks, while mannan was not detected. Most of the feedstocks tested in this study had acid-insoluble lignin content higher than 10-20\% as reported by McMillan [26] for herbaceous species and agricultural residues. The acid-insoluble lignin content is expected to contain lignin and condensed protein, which became insoluble in concentrated sulfuric acid [27, 28]. However, as crude protein accounts for only 3-6\% of the agricultural residue $(w / w)$, and majority of the acid-insoluble material is lignin, the term acidinsoluble lignin has been referred to as such in this study to limit confusion [29].

In general, for the same crops (barley or triticale), the sum of glucan, xylan, and lignin in hays was significantly lower $(p \leq 0.05)$ than that in straws (Table 2$)$. The lignin content of triticale hay was however not significantly different $(p>0.05)$ from that of triticale straw. This difference could be explained by the different harvest stages and forage conservation methods used in the preparation of the feedstocks. Hays are cut, dried, and baled when the crops are still green and premature and typically contain significant amounts of non-fiber carbohydrates such as starch, simple sugars, like glucose or fruc- 
Table 2. Summative percent composition of untreated feedstocks. ${ }^{\text {a }}$

\begin{tabular}{|c|c|c|c|c|c|c|c|c|c|}
\hline Feedstock & $\begin{array}{l}\text { Total } \\
\text { solid }\end{array}$ & $\begin{array}{c}\text { Holo- } \\
\text { cellulose }\end{array}$ & Arabinan & Galactan & Glucan & Xylan & $\mathrm{ASL}^{\mathrm{b}}$ & $\mathrm{AIL}^{\mathrm{c}, \mathrm{d}}$ & Ash \\
\hline $\begin{array}{l}\text { Barley } \\
\text { hay }\end{array}$ & $\begin{array}{l}92.35 \\
(0.49)\end{array}$ & $\begin{array}{l}40.58 \\
(0.64)\end{array}$ & $\begin{array}{c}1.55 \\
(0.07)\end{array}$ & $\begin{array}{c}0.03 \\
(0.04)\end{array}$ & $\begin{array}{l}28.62 \\
(1.77)\end{array}$ & $\begin{array}{l}11.19 \\
(1.06)\end{array}$ & $\begin{array}{l}4.75 \\
(0.18)\end{array}$ & $\begin{array}{l}17.26 \mathrm{~B} \\
(1.06)\end{array}$ & $\begin{array}{c}7.04 \\
(0.08)\end{array}$ \\
\hline $\begin{array}{l}\text { Barley } \\
\text { straw }\end{array}$ & $\begin{array}{l}93.34 \\
(0.13)\end{array}$ & $\begin{array}{l}58.46 \\
(0.78)\end{array}$ & $\begin{array}{c}1.70 \\
(0.21)\end{array}$ & $\begin{array}{c}0.00 \\
(0.00)\end{array}$ & $\begin{array}{l}38.58 \\
(2.27)\end{array}$ & $\begin{array}{l}19.64 \\
(1.43)\end{array}$ & $\begin{array}{l}2.18 \\
(0.04)\end{array}$ & $\begin{array}{l}25.39 \mathrm{~A} \\
(1.35)\end{array}$ & $\begin{array}{l}5.26 \\
(0.08)\end{array}$ \\
\hline $\begin{array}{l}\text { Pearl } \\
\text { millet hay }\end{array}$ & $\begin{array}{l}93.59 \\
(0.42)\end{array}$ & $\begin{array}{l}43.75 \\
(1.21)\end{array}$ & $\begin{array}{c}2.83 \\
(0.07)\end{array}$ & $\begin{array}{c}0.44 \\
(0.05)\end{array}$ & $\begin{array}{l}28.76 \\
(2.99)\end{array}$ & $\begin{array}{l}14.39 \\
(0.67)\end{array}$ & $\begin{array}{c}5.29 \\
(0.06)\end{array}$ & $\begin{array}{l}16.72 \mathrm{~B} \\
(0.59)\end{array}$ & $\begin{array}{c}10.72 \\
(0.08)\end{array}$ \\
\hline $\begin{array}{l}\text { Sweet } \\
\text { sorghum hay }\end{array}$ & $\begin{array}{c}89.01 \\
(0.11)\end{array}$ & $\begin{array}{l}46.21 \\
(0.58)\end{array}$ & $\begin{array}{c}2.01 \\
(0.18)\end{array}$ & $\begin{array}{c}0.38 \\
(0.11)\end{array}$ & $\begin{array}{c}30.36 \\
(1.59)\end{array}$ & $\begin{array}{l}13.08 \\
(0.87)\end{array}$ & $\begin{array}{c}5.65 \\
(0.08)\end{array}$ & $\begin{array}{l}16.39 \mathrm{~B} \\
(1.58)\end{array}$ & $\begin{array}{c}8.45 \\
(0.19)\end{array}$ \\
\hline $\begin{array}{l}\text { Triticale } \\
\text { hay }\end{array}$ & $\begin{array}{l}92.76 \\
(0.07)\end{array}$ & $\begin{array}{l}53.14 \\
(0.92)\end{array}$ & $\begin{array}{c}1.30 \\
(0.10)\end{array}$ & $\begin{array}{c}0.00 \\
(0.00)\end{array}$ & $\begin{array}{l}28.13 \\
(2.27)\end{array}$ & $\begin{array}{l}12.62 \\
(0.98)\end{array}$ & $\begin{array}{l}3.96 \\
(0.18)\end{array}$ & $\begin{array}{l}22.14 \mathrm{~A} \\
(0.43)\end{array}$ & $\begin{array}{c}9.62 \\
(0.38)\end{array}$ \\
\hline $\begin{array}{l}\text { Triticale } \\
\text { straw }\end{array}$ & $\begin{array}{c}95.47 \\
(0.22)\end{array}$ & $\begin{array}{c}56.43 \\
(0.54)\end{array}$ & $\begin{array}{c}2.07 \\
(0.06)\end{array}$ & $\begin{array}{c}0.05 \\
(0.07)\end{array}$ & $\begin{array}{c}35.91 \\
(1.16)\end{array}$ & $\begin{array}{l}20.78 \\
(0.98)\end{array}$ & $\begin{array}{c}2.07 \\
(0.13)\end{array}$ & $\begin{array}{l}23.01 \mathrm{~A} \\
(0.32)\end{array}$ & $\begin{array}{c}8.23 \\
(0.08)\end{array}$ \\
\hline $\begin{array}{l}\text { Wheat } \\
\text { straw }\end{array}$ & $\begin{array}{l}93.44 \\
(0.14)\end{array}$ & $\begin{array}{l}57.42 \\
(1.33)\end{array}$ & $\begin{array}{l}1.70 \\
(0.23)\end{array}$ & $\begin{array}{c}0.00 \\
(0.00)\end{array}$ & $\begin{array}{l}35.66 \\
(2.43)\end{array}$ & $\begin{array}{l}20.28 \\
(1.19)\end{array}$ & $\begin{array}{c}2.22 \\
(0.04)\end{array}$ & $\begin{array}{l}23.17 \mathrm{~A} \\
(0.24)\end{array}$ & $\begin{array}{c}3.64 \\
(0.03)\end{array}$ \\
\hline
\end{tabular}

tose held together by alpha chemical bonds, and pectin [29]. The simple free sugars may be degraded, therefore, decreasing the sugar content in the acid hydrolyzate during the intense hydrolysis with $72 \%$ sulfuric acid used for carbohydrate analysis. On the other hand, straws are senesced crop residues (leaves, stems) left after the grain has been harvested [31]. They are extremely fibrous and of low nutritive value as animal feed [29].

The composition of the feedstocks analyzed in this study is comparable to the wide range of values reported in literature. It has been reported that barley straw contains $35-45 \%$ cellulose, $30-50 \%$ hemicellulose, and 8-20\% lignin [29, 32, 33]; wheat straw contains $30-45 \%$ cellulose, $17-32 \%$ hemicellulose, and $16-23 \%$ lignin [34, 35]; and sweet sorghum contains $27 \%$ cellulose, $25 \%$ hemicellulose, $11 \%$ lignin [34]. These discrepancies in composition may be attributed to growing location, season, stage of harvest, harvesting methods, and analysis procedures [29].

\section{Chemical Pretreatment of Feedstocks}

Chemical selection was based on the fact that alkali pretreatment can cause delignification by breaking the ester bonds cross-linking lignin and xylan, thus, increasing the porosity of biomass [36]. A statistical analysis and ranking of feedstock lignin content was performed (Table 2). Feedstocks which had significantly lower $(p>0.05)$ lignin content (barley hay, pearl millet hay, sweet sorghum hay) were treated with sulfuric acid, while those with significantly higher $(p \leq 0.05)$ lignin content (barley straw, triticale hay, triticale straw, and wheat straw) were treated with $\mathrm{NaOH}$. Effect of chemical treatment on feedstock composition is shown in Table 3. Lignin reduction and xylan solubilization determined by weight loss of lignin and xylan in the pretreated samples are shown in Figures 1 and 2 for acid and alkali pretreatment, respectively. 
Table 3. Summative percent composition of pretreated feedstocks.

\begin{tabular}{|c|c|c|c|c|c|}
\hline Feedstock & Chemical & Conc. $(\%)^{\mathrm{a}}$ & Biomass recovered & Glucan & Ash \\
\hline \multirow[t]{3}{*}{ Barley hay } & $\mathrm{H}_{2} \mathrm{SO}_{4}$ & $0.5 \mathrm{C}$ & $62.62(1.26)$ & $30.90(0.79)$ & $5.04(0.50)$ \\
\hline & $\mathrm{H}_{2} \mathrm{SO}_{4}$ & $1.0 \mathrm{~B}$ & $51.42(0.61)$ & $39.04(0.60)$ & $6.38(0.26)$ \\
\hline & $\mathrm{H}_{2} \mathrm{SO}_{4}$ & $2.0 \mathrm{~A}$ & $47.33(0.62)$ & $47.62(1.45)$ & $6.58(0.40)$ \\
\hline \multirow[t]{3}{*}{ Barley straw } & $\mathrm{NaOH}$ & $0.5 \mathrm{C}$ & $89.23(0.78)$ & $40.63(2.18)$ & $4.72(0.06)$ \\
\hline & $\mathrm{NaOH}$ & $1.0 \mathrm{~B}$ & $68.48(0.70)$ & $51.97(0.91)$ & $4.74(0.82)$ \\
\hline & $\mathrm{NaOH}$ & $2.0 \mathrm{~A}$ & $59.21(3.33)$ & $59.13(3.63)$ & $5.06(0.71)$ \\
\hline \multirow[t]{3}{*}{ Pearl millet hay } & $\mathrm{H}_{2} \mathrm{SO}_{4}$ & $0.5 \mathrm{C}$ & $72.37(1.05)$ & $39.29(2.65)$ & $3.04(0.87)$ \\
\hline & $\mathrm{H}_{2} \mathrm{SO}_{4}$ & $1.0 \mathrm{~B}$ & $56.61(2.51)$ & $46.27(2.23)$ & $4.25(0.74)$ \\
\hline & $\mathrm{H}_{2} \mathrm{SO}_{4}$ & $2.0 \mathrm{~A}$ & $51.63(1.10)$ & $51.74(0.99)$ & $4.44(0.66)$ \\
\hline \multirow[t]{3}{*}{ Sweet sorghum hay } & $\mathrm{H}_{2} \mathrm{SO}_{4}$ & $0.5 \mathrm{C}$ & $68.60(0.82)$ & $34.48(1.83)$ & $2.58(0.29)$ \\
\hline & $\mathrm{H}_{2} \mathrm{SO}_{4}$ & $1.0 \mathrm{~B}$ & $61.55(0.67)$ & $37.93(1.93)$ & $4.21(0.40)$ \\
\hline & $\mathrm{H}_{2} \mathrm{SO}_{4}$ & $2.0 \mathrm{~A}$ & $52.37(0.65)$ & $44.51(0.65)$ & $5.18(0.06)$ \\
\hline \multirow[t]{3}{*}{ Triticale hay } & $\mathrm{NaOH}$ & $0.5 \mathrm{C}$ & $67.60(1.56)$ & $33.94(1.11)$ & $8.69(1.13)$ \\
\hline & $\mathrm{NaOH}$ & $1.0 \mathrm{~B}$ & $55.71(1.73)$ & $37.09(3.85)$ & $9.37(1.04)$ \\
\hline & $\mathrm{NaOH}$ & $2.0 \mathrm{~A}$ & $47.01(0.31)$ & $48.43(0.57)$ & $9.22(0.90)$ \\
\hline \multirow[t]{3}{*}{ Triticale straw } & $\mathrm{NaOH}$ & $0.5 \mathrm{C}$ & $84.37(0.82)$ & $44.24(1.31)$ & $9.62(0.83)$ \\
\hline & $\mathrm{NaOH}$ & $1.0 \mathrm{~B}$ & $71.43(0.78)$ & 48.89 (1.61) & $7.73(0.88)$ \\
\hline & $\mathrm{NaOH}$ & $2.0 \mathrm{~A}$ & $60.05(0.70)$ & $58.14(1.05)$ & $5.30(0.34)$ \\
\hline \multirow[t]{3}{*}{ Wheat straw } & $\mathrm{NaOH}$ & $0.5 \mathrm{C}$ & $87.24(0.37)$ & $42.36(1.36)$ & $5.47(0.78)$ \\
\hline & $\mathrm{NaOH}$ & $1.0 \mathrm{~B}$ & $69.49(0.25)$ & $55.36(1.77)$ & $5.07(0.57)$ \\
\hline & $\mathrm{NaOH}$ & $2.0 \mathrm{~A}$ & $58.94(0.87)$ & $59.48(1.46)$ & $5.36(1.23)$ \\
\hline
\end{tabular}

${ }^{a}$ For a particular feedstock, values in rows followed by the same capital letter are not statistically different. Letter $\mathrm{A}$ indicates the most effective pretreatment based on lignin reduction for alkali pretreated and xylan reduction for acid pretreated.

\section{Effect of acid pretreatment}

Dilute acid treatment is one of the most effective pretreatment methods for lignocellulosic biomass. High temperature results in hemicellulose hydrolysis during this pretreatment, releasing monomeric sugars and soluble oligomers from the cell wall matrix into the hydrolyzate. Hemicellulose removal increases porosity and improves enzymatic digestibility, with maximum enzymatic digestibility usually coinciding with complete hemicellulose removal [26].

Glucan content in the pretreated barley, pearl millet, and sweet sorghum hays increased as the acid concentration increased and ranged, respectively, from 30.90 to $47.62,39.29$ to 51.74 , and 34.48 to $44.51 \%$ after pretreatment with 0.5 to $2.0 \%$ sulfuric acid (Table 3). Compared with untreated feedstocks, $71.90,92.84$, and $76.77 \%$ (dry basis) of the glucan was preserved after $2.0 \%$ acid pretreatment in barley, pearl millet, and sweet sorghum hays, respectively. The pretreated samples contained very low amounts of arabinan (less than $1.78 \%$ ) and galactan (less than $0.30 \%$ ). Xylan content, which made up the largest portion of hemicellulose in the untreated biomass, remained the major hemicellulose component in the pretreated biomass. Acid concentration had a significant effect on the reduction of xylan. Increasing acid concentration from 0.5 to $2.0 \%$ increased xylan removal from $14.04-37.18$ to $78.10-81.27 \%$ in acid pretreated solids (Figure 1). The higher xylan solublization compared with glucan breakdown could be attributed to the fact that xylan is more labile than glucan [26]. Results from this study are comparable to those obtained by Schell et al. [37] and Grohmann et al. [38] who reported $77 \%$ xylan reduction in corn stover at $190^{\circ} \mathrm{C} / 60 \mathrm{~min}$ with $1.35 \%$ acid and more than $80 \%$ reduction of xylan in wheat straw treated with dilute sulfuric acid at $140^{\circ} \mathrm{C}$ for $1 \mathrm{~h}$, respectively. 


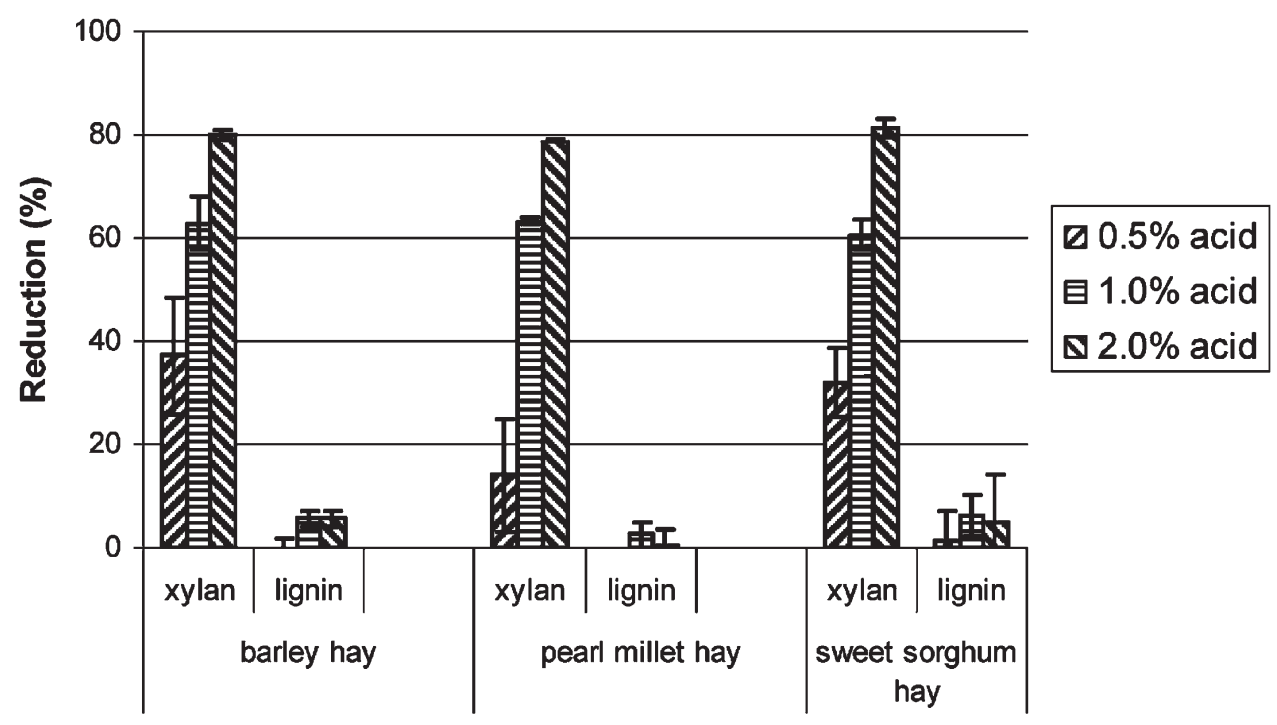

Figure 1. Effect of acid pretreatment on lignin degradation and xylan solubilization in feedstocks.

Compared with untreated feedstocks, lignin content increased after dilute acid treatment and varied from 30.53-35.80\% for barley hay, 22.78-31.39\% for pearl millet hay, and $27.83-33.14 \%$ for sweet sorghum hay. The lignin reduction, however, was significantly lower $(p \leq 0.05)$ than $20 \%$ in all feedstocks subjected to pretreatment with acid concentrations from 0.5 to $2.0 \%$ (Figure 1 ). These results are consistent with other experimental findings indicating that the effect of sulfuric acid pretreatment on lignin degradation is minimal and that lignin reduction is not a substantial contributor in terms of improving enzymatic digestibility [26]. The ash content of pretreated solids was found to be lower than that of the untreated feedstock, which may be attributed to the dissolution of inorganic materials in acid.

\section{Effect of alkali pretreatment}

Using sodium hydroxide to pretreat lignocellulosic materials is an alternative to acid pretreatment. Treatment of biomass with $\mathrm{NaOH}$ causes the disruption of H-bonding in cellulose and hemicellulose, breakage of ester linkages between lignin and xylan, and deprotonation of phenolic groups $[39,40]$. As a result, swelling of cellulose and the partial solubilization of hemicellulose and lignin occur [41, 42].

Glucan content in pretreated samples increased as the alkali concentration increased (Table 3). For barley, triticale, and wheat straws, glucan content ranged from 40.63 to $59.13,44.24$ to 58.14 , and 42.36 to $59.48 \%$, respectively, while for triticale hay, it was between 33.94 and $48.43 \%$ after pretreatment with 0.5 to $2.0 \%$ sodium hydroxide. Compared with untreated feedstocks, 90.94, 80.94, 97.20, and 68.79\% (dry basis) of the glucan in barley straw, triticale hay, triticale straw, and wheat straw, respectively, were preserved after $2.0 \%$ alkali pretreatment. Sodium hydroxide pretreatment also had a significant effect $(p \leq 0.05)$ on the xylan content of pretreated feedstocks. Increasing concentration from 0.5 to $2.0 \%$ increased xylan reduction in alkali pretreated solids (Figure 2). Though the xylan reduction with alkali pretreatment was lower than that with acid pretreatment, the breakdown of xylan, in conjunction with substantial lignin reduction, is expected to significantly improve enzymatic hydrolysis. 


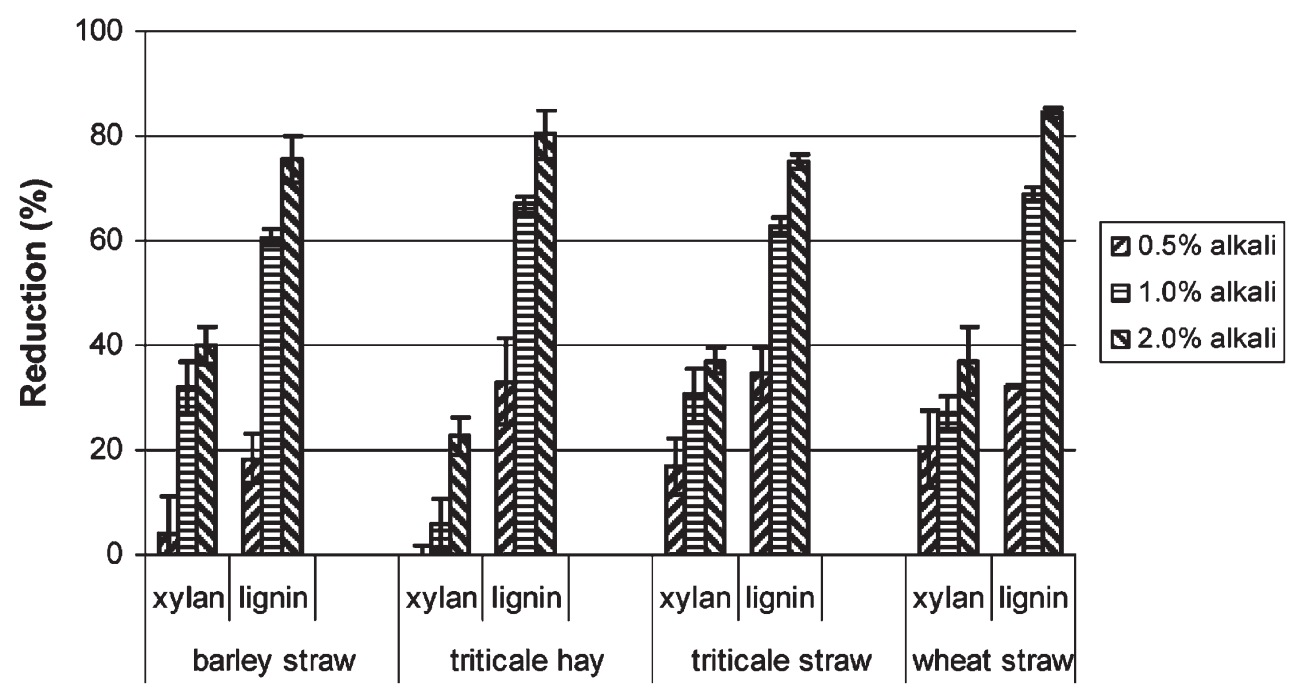

Figure 2. Effect of alkali pretreatment on lignin degradation and xylan solubilization in feedstocks.

The amount of lignin in the feedstocks pretreated with $0.5-2.0 \% \mathrm{NaOH}$ ranged from $10.02-21.88 \%$ for barley straw, $10.16-24.06 \%$ for triticale hay, $10.41-19.03 \%$ for triticale straw, and $6.85-19.17 \%$ for wheat straw. Alkali concentration had a significant effect $(p$ $\leq 0.05$ ) on lignin degradation. Increasing alkali concentration from 0.5 to $2.0 \%$ resulted in lignin reductions between 18.43 and 34.75 to 75.09 and $84.52 \%$ in pretreated feedstocks (Figure 2). This result is comparable with that obtained by Gáspár et al. [43], who reported $95 \%$ lignin reduction in corn fiber treated with $2.5 \% \mathrm{NaOH}$ at $121^{\circ} \mathrm{C} / 60$ min. No significant change in ash content was observed between untreated and alkali pretreated feedstocks.

The optimal $\mathrm{NaOH}$ concentration for alkali pretreatment was determined by statistical analysis based on the effect of chemical concentration on lignin reduction. For acid pretreatment, which did not cause drastic lignin reduction, xylan solublization was used to determine the optimal pretreatment. For all the feedstocks tested, maximum delignification or xylan solubilization was achieved with $2.0 \%$ pretreatment chemical agent (Table 3). As a result, feedstocks treated with $2.0 \%$ acid and alkali treated feedstocks were selected for enzymatic hydrolysis.

The liquid streams obtained during acid and alkaline pretreatment likely contained fermentable sugars and inhibitory substances [furfural, hydroxymethyl furfural (HMF), acetic acid] released from the breakdown of hemicellulose [44]. Recovery and fermentation of sugars from the pretreatment liquid requires either expensive detoxification procedures (overliming, steam stripping, adsorption, ion exchange) or genetically engineered yeast strains [45-47] and was therefore not investigated in this bench scale study.

The percentages of glucan and xylan conversion with enzymatic hydrolysis are reported in Table 4 . The concentrations of arabinose and galactose were below the detection limit of the HPLC and are therefore not reported.

For all the feedstocks, samples containing hydrolytic enzymes released significantly more sugars than the controls $(p \leq 0.05)$, indicating low levels of freely available sugars present in the pretreated feedstocks. Compared to hays, straws released less sugar during enzymatic hydrolysis (Table 4). This may be because hays are premature agricultural products that contain more easily digestible components such as starch, pectin, 
Table 4 Enzymatic hydrolysis of chemically pretreated feedstocks.

\begin{tabular}{|c|c|c|c|c|}
\hline Feedstock & Enzymes & $\begin{array}{l}\text { Enzyme load } \\
\text { (FPU/g glucan) }\end{array}$ & $\begin{array}{l}\text { Glucan } \\
\text { conversion (\%) }{ }^{a, b}\end{array}$ & $\begin{array}{l}\text { Xylan } \\
\text { conversion }(\%)^{a, c}\end{array}$ \\
\hline \multirow[t]{5}{*}{ Barley hay } & Control & 0 & $0.00(0.00) \mathrm{D}$ & $0.00(0.00) \mathrm{B}$ \\
\hline & $\mathrm{C} / \mathrm{Cd}$ & 40 & $94.76(2.86) \mathrm{A}$ & 81.71 (7.49) A \\
\hline & $\mathrm{C} / \mathrm{C}$ & 60 & $96.05(3.00) \mathrm{A}$ & 84.40 (1.72) A \\
\hline & $\mathrm{S} / \mathrm{Xe}$ & 40 & $66.98(4.12) \mathrm{C}$ & $74.04(4.72) \mathrm{A}$ \\
\hline & $S / X$ & 60 & 76.68 (4.64) B & $82.16(5.63) \mathrm{A}$ \\
\hline \multirow[t]{5}{*}{ Barley straw } & Control & 0 & $0.00(0.00) \mathrm{C}$ & $0.00(0.00) \mathrm{D}$ \\
\hline & $\mathrm{C} / \mathrm{C}$ & 40 & 78.09 (4.66) A & 81.45 (3.63) A \\
\hline & $\mathrm{C} / \mathrm{C}$ & 60 & 80.44 (4.08) A & 85.26 (3.32) A \\
\hline & $S / X$ & 40 & 50.25 (3.66) B & 51.44 (3.33) B \\
\hline & $\mathrm{S} / \mathrm{X}$ & 60 & $50.07(4.96) \mathrm{B}$ & 36.05 (8.34) C \\
\hline \multirow[t]{5}{*}{ Pearl millet hay } & Control & 0 & $0.00(0.00) \mathrm{C}$ & $0.00(0.00) \mathrm{B}$ \\
\hline & $\mathrm{C} / \mathrm{C}$ & 40 & $83.38(3.26) \mathrm{A}$ & $84.89(5.03) \mathrm{A}$ \\
\hline & $\mathrm{C} / \mathrm{C}$ & 60 & 76.31 (3.17) B & $83.06(4.61) \mathrm{A}$ \\
\hline & $\mathrm{S} / \mathrm{X}$ & 40 & 75.09 (3.91) B & $86.42(4.66) \mathrm{A}$ \\
\hline & $S / X$ & 60 & $72.89(6.75) \mathrm{B}$ & $79.27(7.40) \mathrm{A}$ \\
\hline \multirow[t]{5}{*}{ Sweet sorghum hay } & Control & 0 & $0.00(0.00) \mathrm{B}$ & $0.00(0.00) \mathrm{C}$ \\
\hline & $\mathrm{C} / \mathrm{C}$ & 40 & 86.67 (7.88) A & $76.94(8.20) \mathrm{A} / \mathrm{B}$ \\
\hline & $\mathrm{C} / \mathrm{C}$ & 60 & 82.17 (4.86) A & 74.26 (7.03) A/B \\
\hline & $S / X$ & 40 & 93.00 (1.73) A & $88.17(9.01) \mathrm{A}$ \\
\hline & $S / X$ & 60 & 81.98 (3.10) A & $66.90(2.73) \mathrm{B}$ \\
\hline \multirow[t]{5}{*}{ Triticale hay } & Control & 0 & $0.73(0.02) \mathrm{C}$ & $0.00(0.00) \mathrm{B}$ \\
\hline & $\mathrm{C} / \mathrm{C}$ & 40 & $100.36(4.97) \mathrm{A}$ & $88.91(2.58) \mathrm{A}$ \\
\hline & $\mathrm{C} / \mathrm{C}$ & 60 & 82.21 (6.69) B & 74.49 (6.68) B \\
\hline & $\mathrm{S} / \mathrm{X}$ & 40 & 101.38 (7.84) A & 86.31 (3.75) A \\
\hline & $\mathrm{S} / \mathrm{X}$ & 60 & 85.54 (7.45) B & 70.07 (4.95) B \\
\hline \multirow[t]{5}{*}{ Triticale straw } & Control & 0 & $0.35(0.19) \mathrm{B}$ & $0.04(0.02) \mathrm{B}$ \\
\hline & $\mathrm{C} / \mathrm{C}$ & 40 & $79.60(6.92) \mathrm{A}$ & $70.29(5.18) \mathrm{A}$ \\
\hline & $\mathrm{C} / \mathrm{C}$ & 60 & 77.45 (5.55) A & $71.25(5.25) \mathrm{A}$ \\
\hline & $\mathrm{S} / \mathrm{X}$ & 40 & $71.62(4.08) \mathrm{A}$ & 77.49 (3.34) A \\
\hline & $\mathrm{S} / \mathrm{X}$ & 60 & $75.50(4.75) \mathrm{A}$ & $75.01(5.74) \mathrm{A}$ \\
\hline \multirow[t]{5}{*}{ Wheat straw } & Control & 0 & $0.36(0.14) \mathrm{C}$ & $0.14(0.13) \mathrm{C}$ \\
\hline & $\mathrm{C} / \mathrm{C}$ & 40 & $79.24(2.26) \mathrm{A}$ & $74.03(5.25) \mathrm{A}$ \\
\hline & $\mathrm{C} / \mathrm{C}$ & 60 & $83.57(3.63) \mathrm{A}$ & $73.71(6.12) \mathrm{A}$ \\
\hline & $\mathrm{S} / \mathrm{X}$ & 40 & $84.59(2.30) \mathrm{A}$ & $69.82(5.84) \mathrm{A}$ \\
\hline & $S / X$ & 60 & $85.46(2.34) \mathrm{A}$ & 75.52 (3.88) A \\
\hline
\end{tabular}

a For a particular feedstock, values in rows followed by the same capital letter are not statistically different. Letter A indicated the highest glucan or xylan degradation.

b Glucan conversion was calculated based on glucose in enzyme hydrolysis supernatant and glucan in pretreated samples.

c Xylan conversion was calculated based on xylose in enzyme hydrolysis supernatant and xylan in pretreated samples.

${ }^{\mathrm{d}} \mathrm{C} / \mathrm{C}$ represents Celluclast $1.5 \mathrm{~L}$ cellulase and cellobiase (Novozyme 188).

e $\mathrm{S}$ X represents Spezyme CP® and xylanase.

and simple sugars, while straws and stalks are mature crop residues which have more structural carbohydrates that are hard to access by enzymes [29-31]. As mentioned previously, in most cases, straws also contain more lignin than hays (Table 2), which further limits the reactivity/enzymatic susceptibility of cellulose and hemicellulose components of the feedstock [48]. 
Statistical analysis showed that Celluclast $1.5 \mathrm{~L}$ supplemented with cellobiase, resulted in equal (for sweet sorghum hay, triticale hay, triticale straw, wheat straw) or higher glucan conversion (for barley hay, barley straw, pearl millet hay) than the combination of Spezyme ${ }^{\circledR}$ CP and xylanase (Table 4). The overall conversion of glucan was between 78.09 and $100.36 \%$ for the feedstocks hydrolyzed with Celluclast $1.5 \mathrm{~L}$ and cellobiase, while the conversion of glucan was between 50.07 and $101.38 \%$ for those hydrolyzed with Spezyme ${ }^{\circledR} \mathrm{CP}$ and xylanase. In lignocellulose hydrolysis, cellulases attack the cellulose chain and release cellobiose, which is then broken down to glucose by $\beta$-glucosidase (cellobiase) [49]. Thus, the presence of sufficient $\beta$-glucosidase is important in reducing the inhibition of cellulase by cellobiose and obtaining high sugar yield [50]. The strains that produce cellulases used in the present study, T. reesei, have been reported to be inefficient $\beta$-glucosidase (cellobiase) secretors [51]. Hence, supplementation of Celluclast $1.5 \mathrm{~L}$ (cellulase), with cellobiase can decrease the concentration of cellobiose in the hydrolyzate, therefore, preventing the possible end product inhibition [52]. Spezyme ${ }^{\circledR} \mathrm{CP}$ on the other hand contains a commercially optimized combination of endoglucanase, exoglucanase, and $\beta$-glucosidase activities $[49,52,53]$ as indicated by the higher $\beta$-glucosidase/cellulase activity in Spezyme® CP than in Celluclast 1.5 L [52]. Agricultural residues contain comparatively higher hemicellulose (mainly xylan) than woody biomass [34], and the addition of xylanase during hydrolysis may increase monomeric sugar yields [16]. As Spezyme® CP already contains cellobiase, supplementation with xylanase is expected to further enhance the sugar conversion from agricultural residues and was therefore investigated in this study. Tengborg et al. [50] observed an increase in cellulose conversion by increasing $\beta$-glucosidase addition for a given cellulase activity. However, beyond a certain concentration, addition of $\beta$-glucosidase did not further improve the cellulose conversion. This finding explains how supplementation of cellulase with $\beta$-glucosidase can improve or achieve the same level of cellulose conversion as with Spezyme® CP cellulase alone.

Increasing enzyme loading to $60 \mathrm{FPU} / \mathrm{g}$ glucan from $40 \mathrm{FPU} / \mathrm{g}$ glucan did not significantly increase $(p>0.05)$ glucan conversion (Table 4$)$. There was an insignificant increase in glucan conversion of barley hay from 94.76 to $96.05 \%$ when enzyme loading was increased, indicating that cellulase loading may have reached saturation at 40 FPU/g glucan. This result is comparable to that obtained by Lloyd and Wyman [54], who reported only $0.1 \%$ decrease in glucose yield when the enzyme loading was reduced from 60 to $15 \mathrm{FPU} / \mathrm{g}$ glucan. Spindler et al. $[55,56]$ also investigated the effect of cellulase activity (7-26 FPU/g cellulose) on ethanol yield from wheat straw and other herbaceous crops. The studies showed an increase in ethanol yield at elevated cellulase loading, but reported a saturation loading of $20 \mathrm{FPU} / \mathrm{g}$ cellulose.

Complete hydrolysis of xylan requires cooperative actions from multiple groups of xylanolytic enzymes [57-59]. The enzymes involved in hydrolysis of the main chain of xylan are $\beta$-D-xylanase which attacks the polysaccharide backbone, and $\beta$-D-xylosidase, which hydrolyzes xylooligosaccharides to xylose [60]. Addition of xylanase during Spezyme® - xylanase hydrolysis did not significantly improve xylan conversion in the feedstocks $(p>0.05)$ (Table 4$)$. Although no xylanase was included in the Celluclast 1.5 L- cellobiase enzyme combination, significant amount of xylose was detected in hydrolyzates. Depending on the feedstocks, the xylose concentration in the hydrolyzate from acid pretreated solid was $2-3 \mathrm{~g} / 1$ and that from alkali pretreated solid was $8-9 \mathrm{~g} / 1$. This was probably due to the presence of xylanolytic activity in Celluclast $1.5 \mathrm{~L}$ and cellobiase [35]. Duarte et al. [61] reported that Celluclast $1.5 \mathrm{~L}$ had $\beta$-xylanase and $\beta$-xylosi- 
Table 5. Fermentation of hydrolyzate from enzymatic hydrolysis of feedstocks.

\begin{tabular}{lccc}
\hline Feedstock & $\begin{array}{l}\text { Glucose in the } \\
\text { hydrolyzate }(\mathrm{g})^{\mathrm{a}}\end{array}$ & $\begin{array}{c}\text { Ethanol yield } \\
(\mathrm{g} / \mathrm{g} \text { sugar })\end{array}$ & ${\text { Ethanol yield }(\%)^{\mathrm{b}}}^{\mathrm{b}}$ \\
\hline Barley hay & $0.38(0.01)$ & $0.30(0.01)$ & $59.34(2.60)$ \\
Barley straw & $0.34(0.02)$ & $0.31(0.01)$ & $60.08(2.45)$ \\
Pearl millet hay & $0.32(0.01)$ & $0.27(0.03)$ & $52.00(4.94)$ \\
Sweet sorghum hay & $0.29(0.03)$ & $0.31(0.03)$ & $60.37(4.16)$ \\
Triticale hay & $0.36(0.01)$ & $0.34(0.02)$ & $65.82(3.02)$ \\
Triticale straw & $0.34(0.03)$ & $0.33(0.01)$ & $63.65(2.64)$ \\
Wheat straw & $0.33(0.02)$ & $0.31(0.02)$ & $59.33(1.46)$ \\
\hline
\end{tabular}

a Indicates total glucose available for fermentation.

${ }^{\mathrm{b}}$ Ethanol yield calculated as a percentage of theoretical maximum ethanol yield [Equation (1)].

dase activities of 100 and $0.53 \mathrm{U} / \mathrm{g}$ xylose, respectively. Saddler et al. [62] tested commercial cellobiase (Novozyme 188) and found that it had a xylanase specific activity even higher than its $\beta$-glucosidase activity. They reported the endoglucanase, $\beta$-glucosidase, filter paper, and xylanase activities of $2.1,10,0.2,11.1 \mathrm{U} / \mathrm{mg}$, respectively. Thus, although no xylanase was supplemented to Celluclast 1.5 L-cellobiase, considerable xylanolytic activity still existed in hydrolyzates from cellulase-cellobiase combination.

Chemical pretreatment reduced hemicellulose (mainly xylan) in the feedstocks. The xylan reduction was, respectively, $78.10-81.27$ and $22.60-39.94 \%$ during $2.0 \%$ acid and $2.0 \%$ alkali pretreatment. It is speculated that the xylanolytic activity in Celluclast 1.5 $\mathrm{L}$ and cellobiose was enough to hydrolyze the reduced amount of xylan after chemical pretreatment.

\section{Fermentation of Hydrolyzates}

The efficiency of glucan and xylan conversions was the basis for identifying hydrolyzates for fermentation. When glucan conversions at the various enzyme loadings of the two enzyme combinations were not significantly different for the various feedstocks (sweet sorghum hay, triticale hay, triticale straw, and wheat straw), xylan conversion was compared to determine the best hydrolysis condition. Considering the high cost of enzymes, hydrolyzates involving the least amount of enzyme were selected for fermentation with S. cerevisiae. Based on the above criterion, enzymatic hydrolysis with Celluclast 1.5 L-cellobiase at enzyme loading of $40 \mathrm{FPU} / \mathrm{g}$ glucan was identified as optimum in this study (Table 4). The results of fermentation of chemically pretreated and enzymatically saccharified feedstocks are summarized in Table 5 . The ethanol yield from the feedstocks tested ranged from 0.27 to $0.34 \mathrm{~g} / \mathrm{g}$ glucose or $52.00-65.82 \%$ of the theoretical maximum ethanol yield.

Wheat straw, which is one of the most widely investigated agricultural residues, has reported ethanol yields of 31-84\% of the theoretical maximum [11, 63-65]. Ethanol yield for barley straw is $60-95 \%$ [32, 66], while information on ethanol from other agricultural residues is scarce in the literature. The ethanol yields obtained in this study are comparable to values in literature, although at the lower end of the reported range. This may be attributed to the fact that feedstock characteristics vary significantly with geographic location, cultivar, and harvest time, and the yeast strain used in this study for fermentation had limited substrate utilization spectrum making it inept at fermenting C5-sugars released from hemicellulose. In addition, chemical pretreatments can lead to the formation of by-products such as furfural, HMF, and phenolic compounds from 
polymer degradation, thereby, inhibiting the fermentation of sugars by yeasts [67]. Although the pretreated biomass was rinsed with DI water before enzymatic hydrolysis, inhibitory substances may have still been present. During enzymatic hydrolysis, tetracycline hydrochloride was used to prevent microbial contamination. This antibiotic could have also contributed to the decreased yeast activity [68]. Besides, no optimization approaches, such as simultaneous saccharification and fermentation, operation of the fermentor in continuous mode rather than batch mode, and selection of the optimal environmental factors that affect fermentation, were investigated in this study.

\section{Conclusions}

Production of bioethanol from agricultural residues (barley hay, barley straw, pearl millet hay, sweet sorghum hay, triticale hay, triticale straw, and wheat straw) through a series of chemical pretreatment, enzymatic hydrolysis, and fermentation experiments was investigated. The following major conclusions can be drawn from this study:

- The feedstocks contain approximately 28.62-38.58\% glucan, $11.19-20.78 \%$ xylan, and $22.01-27.57 \%$ lignin, suggesting that they have potential for bioethanol production. For the same crops (barley or triticale), the sum of glucan, xylan, and lignin in hays was significantly lower than that in straws. The difference could be explained by the fact that hays are young crops that contain a significant amount of non-fiber carbohydrates, while straws are senesced crop residues that are extremely fibrous.

- Feedstocks with comparatively low lignin content were pretreated with sulfuric acid. Sulfuric acid pretreatment resulted in xylan solubilization, which increased with increase in acid concentration. After $2.0 \%$ sulfuric acid pretreatment at $121^{\circ} \mathrm{C} / 15 \mathrm{psi}$ for $60 \mathrm{~min}, 78.10-81.27 \%$ of the xylan in the untreated feedstocks was solubilized. Feedstocks with comparatively high lignin content were pretreated with sodium hydroxide. Alkali pretreatment resulted in increased delignification of the feedstocks at higher alkali concentration. After $2.0 \%$ sodium hydroxide pretreatment at $121^{\circ} \mathrm{C}$ and 15 psi for $60 \mathrm{~min}, 75.09-84.52 \%$ of the lignin in the untreated feedstocks was reduced.

- Enzymatic hydrolysis was performed with two enzyme combinations at two enzyme loadings. Hydrolysis of solids chemically pretreated with $2.0 \%$ acid or alkali by Celluclast 1.5 L-cellobiase resulted in equal or higher glucan and xylan conversion than with Spezyme® CP- xylanase. Increasing enzyme loading from 40 to $60 \mathrm{FPU} / \mathrm{g}$ glucan did not significantly increase the sugar yield. The glucan and xylan conversions during hydrolysis with Celluclast $1.5 \mathrm{~L}$-cellobiase at $40 \mathrm{FPU} / \mathrm{g}$ glucan were 78.09 to $100.36 \%$ and 74.03 to $84.89 \%$, respectively.

- Hydrolyzates from enzymatic hydrolysis with Celluclast $1.5 \mathrm{~L}$ and cellobiase at 40 FPU/g glucan were fermented with S. cerevisiae. The ethanol yield from the feedstocks tested ranged from 0.27 to $0.34 \mathrm{~g} / \mathrm{g}$ glucose or $52.00-65.82 \%$ of the theoretical maximum ethanol yield. The ethanol yields in this study are at the lower end of the reported range, possibly due to the difference in feedstock characteristics and lack of approaches to optimize fermentation process.

This study highlights the potential of cereal grain residues for bioethanol production. Further studies should be focused on enzymatic hydrolysis at lower enzyme load- 
ings and application of pentose and hexose utilizing microorganisms to the fermentation process, as they could not be addressed in this study.

\section{Acknowledgements}

The authors thank Dr. Lisa O. Dean, Food Technologist, USDA-Food Science, NCSU for her assistance with analytical work.

\section{References}

1. Albukh, T. (2000) http://hypertextbook.com/facts/2000/TanyaAlbukh.shtml ; accessed June 20, 2006.

2. Um, B. H., Karim, M. N., \& Henk, L. L. (2003). Applied Biochemistry and Biotechnology, 105-108, 115-125.

3. Ingram, L. O., \& Doran, J. B. (1995). FEMS Microbiology Reviews, 16, 235-241.

4. McKendry, P. (2002). Bioresource Technology, 83, 47-54.

5. USDA (2005) http://usda.mannlib.cornell.edu/reports/nassr/field/pcp-bban/cropan05.pdf ; accessed June 22, 2006.

6. US EPA (2006) http://www.epa.gov/oecaagct/ag101/cropmajor.html ; accessed July 1, 2006.

7. Chen, C., Johnson, D., \& Wichman, D. (2005). The Western Society of Crop Science. Bozeman, MT, June 19-22, 2005.

8. Milne, T. A., Chum, H. L., Agblevor, F. A., \& Johnson, D. K. (1992). Biomass E Bioenergy, 2, 341-366.

9. Delgenes, J. P., Moletta, R., \& Navarro, J. M. (1990). Process Biochemistry, 25, 132-135.

10. Detroy, R. W., Cunningham, R. L., \& Herman, A. I. (1982). Biotechnology and Bioengineering Symposium, 12, 8189.

11. Nigam, J. N. (2001). Journal of Biotechnology, 87(1), 17-27.

12. Saha, B. C., \& Cotta, M. A. (2006). Biotechnology Progress, 22(2), 449-453.

13. Amartey, S., \& Jeffries, T. W. (1996). World Journal of Microbiology \& Biotechnology, 21, 281-283.

14. Chang, V. S., Kaar, W. E., Burr, B., \& Holtzapple, M. T. (2001). Biotechnology Letters, 23(16), 1327-1333.

15. Kim, T. H., \& Lee, Y. Y. (2005). Applied Biochemistry and Biotechnology, 121-124, 1119-1131.

16. Mosier, N., Hendrickson, R., Ho, N., Sedlak, M., \& Ladisch, M. R. (2005). Bioresource Technology, 96(18), 19861993.

17. Parekh, S. R., Parekh, R. S., \& Wayman, M. (1988). Enzyme and Microbial Technology, 10, 660-668.

18. Varga, E., Schmidt, A. S., Reczey, K., \& Thomsen, A. B. (2003). Applied Biochemistry and Biotechnology, 104(1), 37-50.

19. Yang, B., \& Wyman, C. E. (2006). Biotechnology and Bioengineering, 94(4), 611-617.

20. Palmarola-Adrados, B., Choteborska, P., Galbe, M., \& Zacchi, G. (2005). Bioresource Technology, 96, 843-850.

21. Sluiter, A., Hames, B., Ruiz, R., Scarlata, C., Sluiter, J., \& Templeton, D. (2004a). Determination of total solids in biomass. Biomass analysis technology team laboratory analytical procedures. Golden, CO: National Renewable Research Laboratory.

22. Sluiter, A., Hames, B., Ruiz, R., Scarlata, C., Sluiter, J., \& Templeton, D. (2004b). Determination of ash in biomass. Biomass analysis technology team laboratory analytical procedures. Golden, CO: National Renewable Research Laboratory.

23. Sluiter, A., Hames, B., Ruiz, R., Scarlata, C., Sluiter, J., \& Templeton, D. (2004c). Determination of structural carbohydrates and lignin in biomass. Biomass analysis technology team laboratory analytical procedures. Golden, CO: National Renewable Research Laboratory.

24. Han, J., \& Rowell, J. (1997). In R. Rowell, R. Young, \& J. Rowell (Eds.), Paper composites from agro-based resources (pp. 83-134). New York: CRC Lewis Publisher.

25. Chinn, M. S., Nokes, S. E., \& Strobel, H. J. (2006). Biotechnology Progress, 22(1), 53-59.

26. McMillan, J. D. (1994). In M. E. Himmel, J. O. Baker, \& R. P. Overend (Eds.), Enzymatic conversion of biomass for fuels production (pp. 292-324). Washington, DC: American Chemical Society.

27. Agblevor, F. A., Evans, R. J., \& Johnson, K. D. (1994). Journal of Analytical and Applied Pyrolysis, 30, 125-144.

28. Agblevor, F. A., Batz, S., \& Trumbo, J. (2003). Applied Biochemistry and Biotechnology, 105-108, 219-230.

29. McDonald, P., Edwards, R. A., Greenhalgh, J. F. D., \& Morgan, C. A. (1995). In 5th (Ed.), Animal nutrition (pp. 465-480). England: Longman Scientific \& Technical.

30. Arroquy, J. I., Cochran, R. C., Nagaraja, T. G., Titgemeyer, E. C., \& Johnson, D. E. (2005). Animal Feed Science and Technology, 120(1-2), 93-106.

31. Thompson, D. N., Barnes, J. M., \& Houghton, T. P. (2005). Applied Biochemistry and Biotechnology, 121-124, 2146. 
32. Belkacemi, K., Turcotte, G., de Halleux, D., \& Savoie, P. (1998). Applied Biochemistry and Biotechnology, 70-72, 441-462.

33. Sun, Y., \& Cheng, J. J. (2002). Bioresource Technology, 83(1), 1-11.

34. Wiselogel, A., Tyson, S., \& Johnson, D. (1996). In C. E. Wyman (Ed.), Handbook on bioethanol: Production and utilization (pp. 105-119). Washington, DC: Taylor \& Francis.

35. Saha, B. C., Iten, L. B., Cotta, M. A., \& Wu, Y. V. (2005). Process Biochemistry, 40(12), 3693-3700.

36. Sun, J. X., Xu, F., Sun, X. F., Xiao, B., \& Sun, R. C. (2005). Polymer Degradation Stability, 88, 521-531.

37. Schell, D. J., Farmer, J., Newman, M., \& Mcmillan, J. D. (2003). Applied Biochemistry and Biotechnology, 105, 6986.

38. Grohmann, K., Torget, R., \& Himmel, M. (1985). Biotechnology and Bioengineering Symposium, 15, 59-80.

39. Akin, D. E., Hartley, R. D., Rigsby, L. L., \& Morrison, W. H. (1992). Journal of the Science of Food and Agriculture, 58, 207-214.

40. Simpson, A. J., Kingery, W. L., \& Hatcher, P. G. (2003). Environmental Science \& Technology, 37, 337-342.

41. Jackson, M. G. (1977). Animal Feed Science and Technology, 2, 105-130.

42. Scalbert, A., \& Monties, B. (1986). Holzforschung, 40, 249-254.

43. Gáspár, M., Juhász, T., Szengyel, Z., \& Recaéy, K. (2005). Process Biochemistry, 40, 1183-1188.

44. Ohgren, K., Bengtsson, O., Gorwa-Grauslund, M. F., Galbe, M., Hahn-Hagerdal, B., \& Zacchi, G. (2006). Journal of Biotechnology, 126(4), 488-498.

45. Amartey, S. A., Leung, P. C. J., Baghaei-Yazdi, N., Leak, D. J., \& Hartley, B. S. (1999). Proceedings of Biochemistry, 34(3), 289-294.

46. Martinez, A., Rodriguez, M. E., Wells, M. L., York, S. W., Preston, J. F., \& Ingram, L. O. (2001). Biotechnology Progress, 17, 287-293.

47. Mussatto, S. I., Santos, J. C., \& Roberto, I. C. (2004). Journal of Chemical Technology and Biotechnology, 79(6), 590-596.

48. Chung,Y.-C., Bakalinsky, A., \& Penner, M. H. (2005). Applied Biochemistry and Biotechnology, 121-124, 947961.

49. Béguin, P., \& Aubert, J.-P. (1994). FEMS Microbiology Reviews, 13, 25-58.

50. Tengborg, C., Galbe, M., \& Zacchi, G. (2001). Biotechnology Progress, 17, 110-117.

51. Bhat, M. K., \& Bhat, S. (1997). Biotechnology Advances, 15(3/4), 583-620.

52. Nieves, R. A., Ehrman, C. I., Adney, W. S., Elander, R. T., \& Himmel, M. E. (1998). World Journal of Microbiology E Biotechnology, 14, 301-304.

53. Zhou, S., Davis, F. C., \& Ingram, L. O. (2001). Applied and Environmental Microbiology, 67(1), 6-14.

54. Lloyd, T. A., \& Wyman, C. E. (2005). Bioresource Technology, 96, 1967-1977.

55. Spindler, D. D., Wyman, C. E., Grohmann, K., \& Mohagheghi, A. (1989). Applied Biochemistry and Biotechnology, 20/21, 529-540.

56. Spindler, D., Wyman, C., \& Grohmann, K. (1990). Applied Biochemistry and Biotechnology, 24/25, 275-286.

57. Kellett, L. E., Poole, D. M., Ferreira, L. M. A., Durrant, A. J., Hazlewood, G. P., \& Gilbert, H. J. (1990). Biochemical Journal, 272(2), 369-376.

58. Wong, K. K. Y., Tan, L. U. L., \& Saddler, J. N. (1988). Microbiology Reviews, 52, 305-317.

59. Thomson, J. A. (1993). FEMS Microbiology Reviews, 104, 65-82.

60. Biely, P. (1985). Trends in Biotechnology, 3(11), 286-290.

61. Duarte, L. C., Carvalheiro, F., Lopes, S., Marques, S., Parajo, J. C., \& Girio, F. M. (2004). Applied Biochemistry and Biotechnology, 113-116, 1041-1058.

62. Saddler, J. N., Yu, E. K. C., Mes-Hartree, M., Levitin, N., \& Brownell, H. H. (1983). Applied and Environmental Microbiology, 45(1), 153-160.

63. Alfani, F., Gallifuoco, A., Saporosi, A., Spera, A., \& Cantarella, M. (2000). Journal of Industrial Microbiology E Biotechnology, 25(4), 184-192.

64. Ballesteros, M., Oliva, J. M., Negro, M. M., Manzanares, P., \& Ballesteros, I. (2004). Process Biochemistry, 39, 1843-1848.

65. Zhu, S. D., Wu, Y. X., Yu, Z. N., Zhang, X., Wang, C. W., Yu, F. Q., et al. (2006). Process Biochemistry, 41(4), 869-873.

66. Boyle, M., Barron, N., \& McHale, A. P. (1997). Biotechnology Letters, 19(1), 49-51.

67. Bjerre, A. B., Olessen, A. B., Fernqvist, T., Ploger, A., \& Schmidt, A. S. (1996). Biotechnology and Bioengineering, $49,568-577$.

68. D'Haese, D. E., Nelis, H. J., \& Reybroeck, W. (1997). Applied Environmental and Microbiology, 63(10), 41164119. 